\title{
PARADIGMA PEMAHAMAN HADIS
}

(Studi Pemahaman Hadis Berdasarkan Bentuk Matan)

\section{Ermawati}

Institut Agama Islam Negeri (IAIN) Palu

Email: ermawatiusman@gmail.com

\section{Abstract:}

The scholars look for formulas and strategies to explain the meaning of hadith. Many methods, techniques and approaches are offered by hadith scientists to pave the way for understanding hadith so that hadith which is a product of the past can be kept up to date and become a guide for Muslims who are rahmatan lil alamin. To obtain a comprehensive understanding of the matan of hadith, one way is to have knowledge of the form of matan used by the Prophet Muhammad in the expression of hadith. The forms of hadith expressions referred to are Jawamil kalim, tamsil, ramzi, qiyas and conversational forms, which are the privileges of the Prophet Muhammad in conveying hadith. The five features are adapted to the case faced by the Prophet Muhammad, and cannot be focused on a particular hadith. Thus, the language of the Prophet's da'wah has a meaning value package in conveying parables and symbolic expressions for friends' questions. The expression in the form of matan, can be one of the tools in understanding hadith. This paper will describe the traditions that have the forms of matan which contain the five styles of language above, by presenting several examples that are elaborated on the thoughts or understandings of the hadith scholars.

Para ulama mencari formula dan strategi sebagai upaya dalam memahami hadis. Banyak metode, teknik dan pendekatan yang ditawarkan oleh ilmuan hadis untuk membuka jalan bagi pemahaman hadis sehingga hadis yang merupakan produk masa lalu dapat menjadi tetap up to date dan menjadi pedoman umat Islam yang rahmatan lil alamin. 
120 Rausyan Fikr, Vol. 17 No. 1 Januari 2021: 119 - 143.

Salah satu di antaranya penelitian terhadap bentuk Matan, yang sejatinya lebih perlu diintensifkan dibanding penelitian Sanad yang sudah sangat terpenuhi. Penelitian terhadap Matan dan Metodologinya tidak bisa mencapai kata final, karena akan selalu diperhadapkan dengan perubahanperubahan dan problem kemodernan. Untuk memperoleh pemahaman yang komprehensif terhadap matan hadis, salah satunya dengan memiliki pengetahuan tentang bentuk matan yang dipergunakan Nabi Muhammad saw., dalam ungkapan hadis. Bentuk ungkapan hadis yang dimaksud di adalah Jawamil kalim, tamsil, ramzi, qiyas dan bentuk percakapan, yang merupakan keistimewaan Nabi Muhammad saw., dalam menyampaikan hadis. Kelima corak tersebut diadaptasikan pada kasus yang dihadapi Nabi saw., tidak bisa tertuju pada hadis tertentu. Dengan demikian, bahasa dakwah Nabi saw., memiliki kemasan nilai makna dalam menyampaikan perumpamaan maupun ungkapan simbolik untuk pertanyaan sahabat. Ungkapan dalam bentuk matan tersebut, dapat menjadi salah satu alat dalam memahami hadis. Tulisan ini akan memaparkan hadis-hadis yang memiliki bentuk-bentuk matan yang mengandung lima gaya Bahasa di atas, dengan menghadirkan beberapa contoh yang dielaborasi dari pemikiran atau pemahaman dari ulama hadis.

Kata Kunci: Paradigma, Pemahaman Hadis, Matan

\section{PENDAHULUAN}

Dalam hadis terdapat beberapa unsur penting, yaitu sanad dan matan. Bagi ulama hadis, upaya penelusuran keshahihan hadis harus melalui kritik sanad dan matan. Penelitian hadis tidak boleh hanya meneliti sisi periwayatannya saja (al-naqd al-khāriji), akan tetapi haruslah meneliti dari sisi matannya pula (al-naqd al-dākhili), 
Ini dikarenakan dari kondisi hadits yang cukup bervariasi. Hal ini disebabkan karena kadangkala pada hadis kondisi sanadnya shahih, tetapi matannya dha'if, ataupun sebaliknya.

Ulama hadis dalam meneliti matan hadis, memiliki kriteria masing-masing. Matan yang maqbul, menurut al-Khatib al-Bagdadi apabila (1) tidak bertentangan dengan akal yang sehat (2) tidak bertentangan dengan hukum yang terkandung dalam Alquran yang telah muhkam (ketentuan hukum yang telah tetap), (3) tidak bertentangan dengan hadis Nabi yang mutawatir, (4) tidak bertentangan dengan amalan-amalan yang telah menjadi kesepakatan para ulama masa lalu (ulama salaf), (5) tidak bertentangan dengan dalil yang telah memiliki kepastian, dan (6) tidak bertentangan dengan hadis ahad yang kualitas keshahihannya lebih kuat dan tidak diragukan. ${ }^{1}$

Berdasarkan kriteria di atas menunjukkan penelitian matan mesti mendapat perhatian khusus guna menjaga otensitas hadis. Sebab kritik eksternal (sanad) dari satu hadis sama pentingnya dengan kritik internal (matan) dalam menentukan kesahihan satu hadis. $^{2}$

Karenanya dalam memahami hadis, perlu mengetahui konteks yang menjelaskan situasi dan kondisi munculnya hadis (asbab al-wurud), sehingga diketahui maksudnya dengan seksama, bukan atas dasar perkiraan semata atau dipahami sesuai dengan makna lahiriyah yang jauh dari tujuan sebenarnya. Dengan demikian, pemahaman terhadap hadis bisa lebih komprehensif. Untuk itu, perlunya memahami teori-teori dari berbagai disiplin ilmu termasuk ilmu sosial seperti sosiologi, antropologi, psikologi maupun faktor linguistik untuk memahami hadis Nabi.

\footnotetext{
${ }^{1}$ M. Syuhudi Ismail, Metodologi Penelitian Hadits Nabi, (Jakarta: Bulan Bintang, 1988 ), 126.

${ }^{2}$ Muhammad Patri Arifin, "Obat Penawar dan Penyakit di Sayap Lalat (Integrasi-Interkonektif Hadis dengan Ilmu Pengetahuan)”, al-Munir: Jurnal Studi Ilmu al-Qur' an dan Tafsir, Vol. 2, No. 2 Juli 2020: 93-110.
} 
Dalam perkembangannya, banyak cara memahami hadis yang ditawarkan, di antaranya oleh Muhammad Iqbal, yang menyatakan bahwa hadis Nabi harus dipahami secara kontekstual, hal ini menuntut untuk memperhatikan latar sosiologis dan kondisi pada masa Nabi dan zaman sekarang melelalui penelitian dan telaah sejarah yang mendalam. Dalam penerapan aspek metodeloginya, Muhammad Iqbal lebih memfokuskan pada hadis-hadis hukum. Muhammad Iqbal memberi penilaian bahwa, ketika seseorang ingin mempergunakan hadis, maka, (1) harus memilah dan memilih hadis-hadis yang membawa konsekuensi hukum dan yang tidak memiliki konsekuensi; (2) harus dianalisa terlebih dahulu, sejauh mana hadis-hadis hukum tersebut mengandung berbagai kebiasaan bangsa Arab pra Islam yang membiarkan beberapa kasus tetap berjalan dan beberapa kasus lain diperbaiki oleh Nabi saw. ${ }^{3}$

Lain halnya menurut Yusuf al-Qaradawi, dalam memahami hadis setidaknya ada tiga karakteristik yang perlu ditinjau: (1) komprehensif (manhaj syumuli), yaitu manhaj bahwa hadis Nabi saw. mencakup keseluruhan dimensi kehidupan manusia yang dapat diimplementasikan di semua situasi dan kondisi pada berbagai zaman, (2) seimbang (manhaj mutawazin), yaitu bahwa hadis Nabi saw., selalu mempertimbangakan keseimbangan antara tubuh, jiwa, akal dan kalbu manusia, baik dunia dan akhirat, secara ideal dan realitas, teori maupun praktek, alam gaib dan kasat mata, kebebasan dan tanggungjawab, kebutuhan individu ataupun masyarakat, ittiba' dan ibtida' dan seterusnya, (3) memudahkan (manhaj muyassar), yaitu bahwa hadis Nabi saw. Bersifat sangat memudahkan dan tidak memberikan beban yang berlebihan atau tidak semestinya. ${ }^{4}$

\footnotetext{
${ }^{3}$ Muhammad Iqbal, Recontruction of Religius Though in Islam, (New Delhi: Kitab Bhavan, 1981 M.), 171.

${ }^{4}$ Yusuf al-Qardawi, Kaifa Nata'amal Ma'a al-Sunnah al-Nabawiyyah (al-Mansurah: Dar alWafa', 1990), 23-25.
} 
M. Syuhudi Ismail dalam kajiannya lebih menekankan pemahaman hadis Nabi saw terhadap berbagai varian makna, baik secara tekstual dan kontekstual. Perbedaan ini dapat dilakukan dengan (1) memperhatikan sisi-sisi linguistik hadis terkait gaya bahasa, seperti Jawami' alKalim (pernyataan-pernyataan singkat namun bermakna luas), tamsil (perumpamaan), ungkapan simbolik, bahasa percakapan dan ungkapan analogi. (2) melibatkan telaah atau penelitian sejarah yang terkait peran dan fungsi Nabi saw serta situasi dan kondisi yang telah memunculkan adanya hadis. ${ }^{5}$

Di antara kekhususan yang dimiliki Nabi saw., adalah beragamnya bentuk matan. Dilihat dari segi bentuk matannya, hadis Nabi ada yang berupajamial-kalim (ungkapan yang singkat, namun padat makna), tamsil (perumpamaan), ramzi (bahasa simbolik), dialog (bahasa percakapan), qiyasi (ungkapan analogi), mengandung kosa kata yang gharib (asing), atau pernyataan yang musykil.

Tulisan ini akan menyajikan pemahaman matan hadis berdasarkan bentuk ungkapan bahasa dalam matan hadis, yang dengan beragamnya bentuk ungkapan dalam matan hadis menjadi menarik disebabkan oleh keunikan style bahasa Nabi saw., dalam menyampaikan berita. Sehingga, menunjukkan hadis memiliki taste bahasa yang tidak serampangan, sebagaimana salah satu kriteria bahasa dalam matan hadis.

\section{SEJARAH MEMAHAMI HADIS}

Keberadaan pemahaman hadis telah terjadi selama Nabi Muhammad saw., masih hidup. Problem yang muncul dalam perbedaan pandangan memahami hadis dapat diselesaikan dengan keterangan langsung dari Nabi saw., contoh ketidakseragaman dalam memahami hadis tentang "janganlah kalian shalat ashar kecuali setelah sampai di daerah Bani Quraizhah”.

${ }^{5}$ M. Syuhudi Ismail, Hadis Nabi . . , 7-21. 
Sebagian sahabat memahami secara substansial hadis tersebut merupakan perintah untuk bergegas dalam perjalanan agar dapat tiba di tempat tujuan pada waktu Asar, kalaupun waktu Asar sudah tiba tapi belum sampai di tempat tujuan, maka boleh salat Asar dimana saja, tidak harus menundanya sesampai di perkampungan Bani Quraidzah, tidak sebagaimana bunyi teksnya yang melarang salat Asar kecuali di perkampungan Bani Quraidhah. Sedangkan sahabat yang lain memahaminya berbeda, menurut mereka, hadis tersebut adalah pesan Rasulullah untuk salat Asar di perkampungan Bani Quraidhah dan tidak boleh salat di lain tempat meski waktu salat Asar telah masuk. Saat Kembali dari Bani Quraizah, para sahabat menceritakan peristiwa tersebut dan Nabi saw., membenarkan kedua pemahaman tersebut. ${ }^{6}$

Sepeninggal Nabi saw., tidak ada lagi otoritas tertinggi dalam pemahaman hadis, sehingga para sahabat melakukan interpretasi semakin beragam terhadap hadis. Hal ini didukung pula oleh fakta kesenjangan kapasitas antar sahabat dalam mencerna hadis, disebabkan ketidaksamaan intensitas kebersamaan mereka bersama Nabi. ${ }^{7}$

Al-Darimi menyimpulkan, paling tidak ada tiga tahapan yang dilakukan oleh sahabat dalam memahami hadis, pasca wafatnya Nabi, yaitu dengan mengonfirmasikannya dengan Alquran, mengonfirmasikan dengan hadis yang lebih baik kualitas kesahihannya dan terakhir menggunakan rasio. ${ }^{8}$

Tradisi pemahaman hadis berlanjut pada masa tabiin, tabi' tabiin, yang ditandai dengan lahirnya berbagai aliran politik yang turut mewarnai pemahaman terhadap hadis, dengan lahirnya kitab

${ }^{6}$ Ahmad al-Qastalani, Irsyad al-Sari Li Syarh Sahị al-Bukhari, jilid II (Beirut: Dar al-Fikr, 1990), 713.

${ }^{7}$ Salahal-Din al-Adlabi, Manhaj Naqd al-Matn (Beirut: Dar al-Afaq alJadidah, 1983), 105.

${ }^{8}$ al-Darimi, Sunan al-Darimi, (Indonesia: Maktabat Dahlan ,t.th) 61,79, dan 95 . 
syarah pada abad ke 14. Kitab-kitab yang sangat membantu, namun di sisi lain, membuat umat Islam berada pada posisi aman dalam memahami hadis karena telah terbantu dengan keberadaan kitabkitab syarah hadis.

Di masa kontemporer, lahirnya para ahli berupaya untuk mencari solusi dengan mengkaji ulang beberapa metode dan pendekatan yang digunakan dalam memahami hadis. Para ahli hadis tersebut berasal dari kalangan Muslim, di antaranya Salahuddin alAdlabi, Nurudin Itr, Ajjaj al-Khatib, Muhammad al-Gazali, Yusuf al-Qardhawi, Syuhudi Ismail, Nabia Abbot, Fuat Seizgein. Sedangkan dari kalangan orientalis, di antaranya Sprenger, Gustav Weil, Josef Schaht, Juynboll, Harald Motski dan lain-lain.

\section{TIPOLOGI MEMAHAMI HADIS}

Terdapat beberapa Teknik dalam memahami hadis:

\section{Tekstual}

Tekstual berasal dari kata teks yang bermakna kata-kata asli dari pengarang. ${ }^{9}$ Tekstual berarti memahami makna dan maksud yang terkandung dalam hadis-hadis Nabi saw., dengan bertumpu pada analisis teks hadis.

Pendekatan secara tekstual merupakan pendekatan yang paling awal digunakan dalam memahami hadis-hadis Nabi saw. Hal ini dimaksudkan bahwa dalam memahami sebuah teks maka terlebih dahulu dengan mengungkap makna asalnya, makna yang populer dan mudah dipahami dengan cara bertumpu pada analisis teks hadis. Pendekatan melihat berbagai makna kata dan struktur gramatika teks hadis, yang tentu saja menjadikan dominasi teks sangat kuat. Teks menjadi bagian yang sangat urgen dalam konstelasi pemahaman pesan-pesan Nabi saw., sehingga makna konteks kadang terabaikan. Di lain sisi, pendekatan tekstual cenderung melahirkan kesimpulan yang sangat parsialistik. Hal ini

${ }^{9}$ W.J.S. Poerwadarminta, Kamus Umum Bahasa Indonesia (Jakarta: Balai Pustaka, 1985), 1035. 
disebabkan karena teks tidak diletakkan dalam konstelasi hadishadis Nabi saw yang lebih luas sehingga tidak terlalu membutuhkan hadis-hadis yang lain dalam menganalisisnya. Walaupun ada kaitannya dengan hadis-hadis lain, terbatas pada kepentingan analisis teks tertentu, seperti dalam 'am dan khash, mutlaq dan muqayyad.

Pemahaman tekstual tidak mempertimbangkan bentuk dan cakupan petunjuk, kapan dan apa sebab terjadinya, serta kepada siapa hadis itu ditujukan; bahkan tidak mempertimbangkan dalildalil yang lainnya. Karena itu, setiap hadis Nabi yang dipahami secara tekstual berarti petunjuk yang dikandung di dalamnya bersifat universal. ${ }^{10}$ Sebagai contoh:

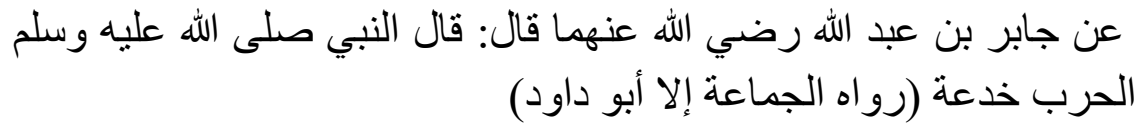

Artinya: "Dari Jabir bin abdillah ra, rasulullah saw bersabda: Perang itu siasat". ${ }^{11}$

Pemahaman terhadap petunjuk hadis tersebut sejalan dengan bunyi teksnya, bahwa setiap perang pastilah memakai siasat. Ketentuan tersebut berlaku secara universal sebab tidak terikat oleh zaman. Dengan demikian dapat dipahami bahwa perang yang dilakukan dengan cara dan alat apa saja pastilah memerlukan suatu siasat. Tanpa siasat sama dengan menyatakan takluk atau menyerah kepada lawan yang dihadapi tanpa syarat. ${ }^{12}$

${ }^{10}$ Arifuddin Ahmad, Paradigma Baru Memahami Hadis Nabi: Refleksi Pemikiran Pembaharuan Prof. Dr. Muhammad Syuhudi Ismail, (Cet. I; Jakarta: Renaisan, 2005), 205

${ }_{11}$ Abu Husain Muslim Bin Hujjaj al-Qusyari al-Naisaury, Shahih Muslim, Juz III, (Beirut: Dar al-Kutub al-Ilmiyah, 1996), 1361.

${ }^{12}$ H.M. Syuhudi Ismail, Hadits Nabi yang Tekstual dan Kontekstual, (Tela'ah Ma'ni al-Hadits tentang Ajaran Islam yang Universal, Temporal dan Loka). (Cet. I; Jakarta: PT. Bulan Bintang, 1994), 11. 


\section{Kontekstual}

Kontekstual berasal dari kata dalam bahasa Inggris, yaitu context, yang berarti "suasana", "keadaan". ${ }^{13}$ Dalam penjelasan lain disebutkan ia berarti; pertama, bagian dari teks atau pernyataan yang meliputi kata atau bagian tertulis tertentu yang menentukan maknanya; dan kedua, situasi di mana suatu peristiwa terjadi.

Kontekstual dapat diartikan sesuatu yang berkaitan dengan atau bergantung pada konteks. Jadi pemahaman kontekstual adalah pemahaman yang didasarkan bukan saja pada pendekatan segi kebahasaan, melainkan juga teks yang dipahami melalui situasi dan kondisi ketika teks itu dimunculkan atau disampaikan. Kontekstual adalah upaya untuk melihat hubungan antar kalimat yang terdapat dalam suatu naskah hadis atau matan hadis, karena hubungan katakata menjadi sangat penting untuk memahami apa yang telah dikatakan. Dengan demikian, maka pemahaman hadis secara kontekstual dimaksudkan adalah memahami hadis dengan melihat sisi-sisi konteks yang berhubungan dengan hadis tersebut.

Pemahaman kontekstual tidak hanya mempertimbangkan konteks, namun juga meliputi bentuk atau cakupan petunjuknya, kapasitas Nabi tatkala hadis itu dikeluarkan, kapan dan apa sebab hadis itu disabdakan, serta kepada siapa ditujukan bahkan dengan mempertimbangkan dalil-dalil lainnya. Dengan demikian, pemahaman secara kontekstual memerlukan kegiatan ijtihad. Hadis Nabi yang dipahami secara kontekstual menunjukkan bahwa ternyata ada hadis yang sifatnya universal, dan ada yang temporal dan lokal. ${ }^{14} \mathrm{Hal}$ inilah yang menunjukkan bahwa keadaan sosial kemasyarakatan dan tempat serta waktu terjadinya, memungkinkan utuhnya pemaknaan terhadap hadis yang disampaikan, dimana dan untuk tujuan apa ia diucapkan, sekiranya dipadukan secara harmoni

${ }^{13}$ W.J.S. Poerwadarminta, Kamus Umum...,35

${ }^{14}$ Arifuddin Ahmad, Paradigma Baru Memahami Hadis Nabi: Refleksi Pemikiran Pembaharuan Prof. Dr. Muhammad Syuhudi Ismail, (Cet. I; Jakarta: Renaisan, 2005), h. 2 
128 Rausyan Fikr, Vol. 17 No. 1 Januari 2021: 119 - 143.

dalam suatu pembahasan. Untuk itu, pendekatan ini dapat dimanfaatkan sehingga diperoleh hal-hal yang bermanfaat secara optimal dari hadis yang disampaikan sehingga maksud hadis benarbenar menjadi jelas dan terhindar dari berbagai perkiraan yang menyimpang.

Berikut ini contoh hadis Nabi saw., dari Abdullah bin Umar menyatakan:

إ ذا جاء أحدكم الجمعة فليختسل (رو اه البخارى ومسلم و غيرهما)

Artinya :"Apabila kamu sekalian hendak datang (mendirikan shalat) jum'at, maka hendaklah terlebih dahulu mandi". (H.R. Bukhari dan Muslim, dan lain-lain). ${ }^{15}$

Hadis di atas, secara tekstual dipahami bahwa hukum mandi pada hari Jum'at adalah wajib, dengan sebab khusus. Pada saat itu, ekonomi para sahabat Nabi saw. umumnya masih dalam keadaan yang sulit. Mereka menggunakan pakaian (baju) wol yang kasar dan jarang dicuci. Mereka banyak menjadi pekerja kebun. Setelah mereka menyiram tanam-tanaman atau beraktifitas, mereka banyak yang langsung pergi ke masjid untuk menunaikan shalat jum'at, dikala itu cuaca yang sangat panas dan masjid masih sempit. Tatkala nabi berkhutbah, aroma keringat dari orang-orang yang berbaju wol kasar dan jarang mandi itu menerpa hidung Nabi, sehingga suasana dalam mesjid ketika itu terganggu oleh aroma yang tidak sedap tersebut. Lalu Nabi bersabda dengan hadis tersebut atau yang semakna. ${ }^{16}$

Dalam riwayat lain bahwa petunjuk Nabi saw secara lebih tegas lagi sebagaimana dari Abu Said al-Khudriy, menyatakan:

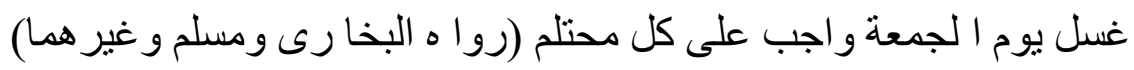

${ }^{15} \mathrm{Abu}$ Abdillah Muhammad bin Ismail Ibn Ibrahim bin al-Mughirah bin Bardzabah al-Bukhari al-jafy, Shahih Bukhari, Juz I, (Beirut: Dar al-Kutub alIlmiyyah, t, th), h. 263.

${ }^{16}$ M. Syuhudi Ismail, Hadits Nabi yang...., op. cit., h. 58-59 
Artinya: "mandi pada hari Ju'mat adalah wajib atas setiap orang yang telah bermimpi (baligh)." (H.R. Bukhari, Muslim, dan lain-lain)."

Melalui pertimbangan adanya peristiwa yang mendahului terjadinya hadis di atas menjadikan perlunya pemahaman hadis tersebut secara kontekstual. Bagi masyarakat yang sudah terbiasa dalam hidupnya mandi sehari dua kali, aroma mereka tidak mengganggu orang-orang yang berada di sekitarnya, maka mandi Jum'at bagi mereka tidak wajib. Bagi anggota masyarakat yang jarang mandi dan jarang berganti pakaian yang digunakan, sehingga aroma badan dan pakaian yang ditimbulkan dapat mengganggu orang-orang di sekitar mereka, maka mereka dikenakan kewajiban untuk mandi sebelum melaksanakan shalat Jum'at.

\section{Intertekstual}

Secara bahasa, interteks terbentuk dari dua kata yaitu kata inter dan teks. Inter artinya jaringan atau hubungan, sedangkan teks (terserap dari bahasa latin textus) berarti tenunan, anyaman, penggabungan, susunan dan jalinan. Jadi interteks dimaksudkan sebagai jaringan hubungan antara satu teks dengan teks lainnya. Hubungan yang dimaksud tidak semata-mata sebagai hubungan persamaan, melainkan juga sebaliknya sebagai sebagai pertentangan. Berdasarkan hai ini maka dapat di pahami bahwa kajian intertekstualitas adalah sebagai kajian terhadap sejumlah teks (sastra), yang diduga mempunyai hubungan-hubungan atau jalinan tertentu. ${ }^{17}$

Memahami hadis Nabi secara intertekstual dapat diartikan dengan memahami hadis dan hubungannya dengan hadis lain atau antara hadis dengan ayat. Misalnya :

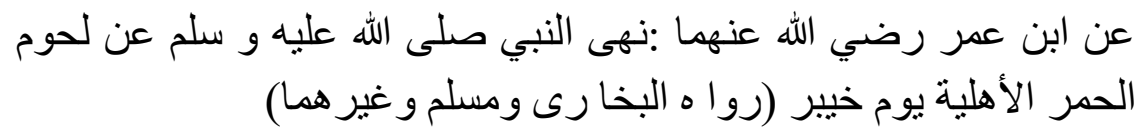

${ }^{17}$ Zailani, Metode Intertekstual Memahami Hadis Nabi, (Al-Fikra: Jurnal Ilmiah Keislaman, Vol. 15, No. 2, Juli - Desember 2016), 299 
130 Rausyan Fikr, Vol. 17 No. 1 Januari 2021: 119 - 143.

Artinya:"Hadis riwayat dari Ibnu Umar r.a, Nabi saw. melarang memakan daging himar (keledai) kampung pada peperangan Khaibar." (H.R. Bukhari, Muslim, dan lainlain)."

Hadis tersebut memberi petunjuk bahwa Rasulullah memiliki kewenangan menetapkan hukum yang dalam Alquran tidak dinyatakan. Pandangan tersebut cukup beralasan bila melihat dari kejelasan isi teks hadisnya, yang kemudian dihubungkan dengan hadis lain, yaitu:

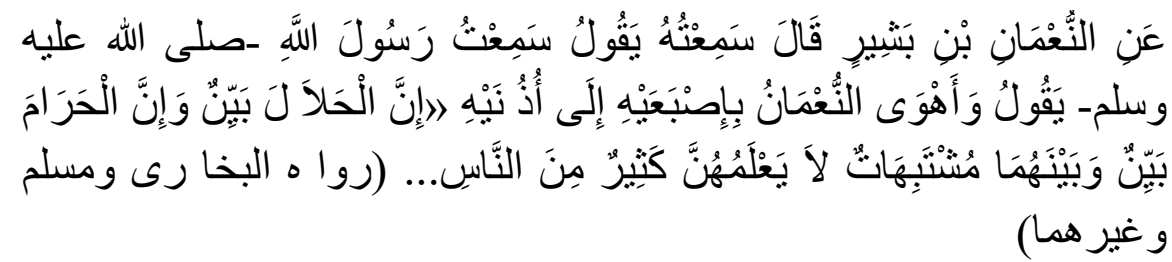

Artinya : "Hadits riwayat al-Nu'man bin Basyir, dia berkata: saya telah mendengar dia berkata: Saya mendengar Rasulullah saw bersabda, (al-Nu'man bin Basyir kemudian menunjuk kearah kedua telinganya dengan kedua jari telunjuknya),: Sesungguhnya yang halal itu telah jelas dan yang haram telah jelaas pula, sedangkan (hal-hal) di antara keduanya adalah samar-samar, kebanyakan manusia tidak mendengar tentang yang samar-samar itu...."18

Hadis di atas menerangkan bahwa hukum halal dan haram untuk berbagai hal telah jelas, tetapi masih ada pula hal-hal yang hukumnya samar-samar dan hanya sedikit orang yang mengetahui hukum yang samar-samar tentang hal-hal yang tertentu itu. Yang mengetahui kondisi tersebut adalah para mujtahid yang tetap bersandar kepada dalil-dalil naqli, baik Alquran maupun hadis.

Dalam fungsi hadis sebagai bayan al-ta'kid dan bayan altafsir bagi Alquran di contohkan dalam hadis berfungsi sebagai bayan al-ta'kid bagi Alquran adalah :

${ }^{18}$ M. Syuhudi Ismail, Hadis Nabi menurut Pembela, Pengingkar dan Pemalsunya. (Cet. I; Jakarta: Gema Insani Press, 1995), h. 100. 


$$
\begin{aligned}
& \text { ألا أنبئكم بأ كبر الكبائر. قالو ا بلى با رسول الله قال: الإشر اك بالله و عقوق }
\end{aligned}
$$

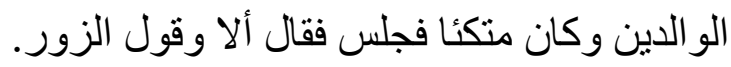

Artinya: "Tidakkah kamu sekalian ingin aku jelaskan tentang dosa yang paling besar? Sahut kami (para sahabat) : Ya Rasulullah, Beliau bersabda (yaitu) menyekutukan Allah, berbuat durhaka kepada kedua orang tua, (saat itu Rasulullah saw sedang bersandar, tiba-tiba duduk seraya bersabda lagi: Awas ingat pula) yaitu bersaksi palsu (H.R. Bukhari dan Muslim). ${ }^{19}$

Hadis di atas menjadi penetapan yang menggarisbawahi ayat Alquran QS. al-Haj: 30.

$$
\text { و اجتنبوا قول الزور }
$$

Terjemahnya: "dan jauhilah perkataan-perkataan dusta."20

Dalam memahami hadis secara tekstual, kontekstual dan intertekstual, yang perlu mendapat perhatian juga adalah kedudukan Nabi saw. dalam kehidupannya yang bukan hanya sebagai Rasul, semakin menjadikan hadis terbuka untuk dipahami di luar teksnya. terdapat lima fungsi Nabi Saw dalam kehidupannya di tengah para sahabat-sahabatnya. Pertama, sebagai rasul dan kriteria itu pasti benar sebab bersumber dari Allah swt. Kedua, sebagai seorang mufti yang memberi fatwa berdasarkan pemahaman dan wewenang yang diberikan Allah swt. kepadanya. Dan ini pasti benar dan berlaku umum bagi setiap kaum muslim. Ketiga, sebagai hakim yang memutuskan perkara. Dalam aspek ini putusan tersebut walaupun secara formal dianggap benar namun secara secara material adakalanya keliru. Keempat, sebagai pemimpin suatu masyarakat kala itu, maka beliau menyesuaikan sikap, bimbingan dan petunjuknya sesuai dengan situasi dan budaya masyarakat yang beliau temui. Namum bagi masyarakat yang lain, mereka dapat

${ }^{19}$ Abududdin Nata, Metodologi Studi Islam, (Cet. II; Jakarta: PT. Rajagrafindo Persada, 2007), h. 242.

${ }^{20}$ Departemen Agama RI., op. Cit., h. 335. 
132 Rausyan Fikr, Vol. 17 No. 1 Januari 2021: 119 - 143.

mempelajari nilai-nilai yang terkandung dalam petunjuk dan bimbingan itu untuk diterapkan sesuai kondisi masing-masing masyarakat. Kelima, sebagai seorang pribadi baik karena beliau memiliki keistimewahan dan hak-hak tertentu yang dianugerahkan atau dibebankan oleh Allah swt dalam rangka tugas kenabiannya maupun kekhususan yang diakibatkan oleh sifatnya sebagai manusia yang berbeda antara seorang dengan yang lain. ${ }^{21}$

Berdasarkan kelima fungsi Nabi saw., maka setiap hadis dapat dipahami dengan memperhatikan kedudukan beliau ketika menyampaikan hadis-hadisnya. Hal ini disebabkan oleh kedudukan Nabi saw., ketika menyampaikan hadis akan sangat menentukan pesan hadis yang sebenarnya. Dengan kata lain, konteks Nabi ketika menyampaikan hadis menentukan muatan hadis yang disampaikannya. Untuk itu, tinjauan terhadap konteks hadis menjadi sangat penting ketika pemahaman terhadap teks hadis belum mampu mengungkap makna hadis sebenarnya yang tersirat dibalik teks itu. Termasuk dalam signifikansi kontekstualisasi pemaknaan hadis adalah menggali pesan moral dari hadis tersebut. Untuk itu perlu memperhatikan konteks sejarahnya, yang menyangkut dengan konten kepada siapa hadis itu disampaikan Nabi saw, atau dalam kondisi sosio kultural masyarakat yang bagaimana saat Nabi menyampaikan hadisnya. Tanpa memperhatikan konteks sjarah lahirnya hadis akan sulit menangkap dan memahami makna suatu hadis, bahkan bisa terjadi pemaknaan dan pemahaman yang keliru. Pendekatan kontekstual diharapkan mampu memberikan pemahaman hadis yang tepat, apresiatif dan akomodatif terhadap perubahan dan erkembangan jaman. Dengan demikian, hadis Nabi saw sebagai penjelas Alquran, secara teologis

${ }^{21}$ M. Quraish Shihab, "Kata Pengantar" dalam Muhammad al-Ghazali, Studi Kritis atas Hadis Nabi SAW Antara Pemahaman Tekstual dan Kontekstual, terjemah: Muhammad al-Baghir (Cet. 5, Bandung: Mizan, 1996), 9. 
juga diharapkan dapat memberi penjelas untuk membantu menyelesaikan problem-problem yang dihadapi dalam masyarakat kontemporer yang hidup bergelimang dengan teknologi modern.

\section{RAGAM BENTUK MATAN DALAM MEMAHAMI HADIS}

Hal yang menarik untuk dikaji adalah cara Nabi saw., menyampaikan berita, Nabi memiliki style atau trik penyampaian yang beragam. Di antaranya berupa penyampaian dalam bentuk jami' al kalim yaitu ungkapan yang singkat, namun sangat sarat makna); tamsil (sebuah perumpamaan); ragam bahasa simbolik (ramzi); bahasa percakapan (dialog); ungkapan analogi (dalam bentuk qiyash); ${ }^{22}$ dan lain sebagainya. Perbedaan bentuk matan hadits ini menunjukkan bahwa pemahaman terhadap hadis Nabi saw., pun berbeda-beda.

\section{Jawamil Kalim.}

Jawamil kalim merupakan bentuk plural dari jami' yang berarti sekumpulan adalah ungkapan yang singkat, namun sangat padat maknanya.

بعثت بجو امع الكلام (رو اه البخارى ومسلم وغير ها عن أبى هريرة)

Artinya: "Saya diutus (oleh Allah) dengan (kemampuan untuk menyatakan) ungkapan-ungkapan yang singkat, namun padat makna". (HR. al-Bukhari, Muslim dan lainlain, dari Abu Hurairah)"

Di antara kelebihan atau keistimewaan Nabi adalah kemampuan menyatakan bahasa atau ungkapan yang singkat, namun memiliki makna yang sangat padat. Adapun contoh matan hadis mengandung jawamil kalim:

$$
\text { كل مسكر خمر وكل مسكر حر ام (رو اه البخاري)23 }
$$

${ }^{22}$ Arifuddin Ahmad, Paradigma Baru Memahami Hadis Nabi..., 3

${ }^{23}$ Al Bukhari, Shahih Bukhari, Juz IV, Dar Kutub Al Islamiyah, Beirut, 1992, hal. 240 
134 Rausyan Fikr, Vol. 17 No. 1 Januari 2021: 119 - 143.

Artinya: "Setiap yang minuman yang memabukkan adalah khamar dan setiap minuman yang memabukkan adalah haram." (HR. Bukhori)

Dalam memahami hadis berupa ungkapan jawami' al kalim haruslah melihat bagaimana kondisi atau latar belakang hadis itu muncul. Dilihat dari segi kebahasaan yang padat dan singkat namun mengandung arti yang sangat mendalam, hadis jawami' al kalim ini dapat dipahami melalui gramatika susunan kalimatnya.

Hadis tentang "perang adalah tipu daya" mengandung banyak fungsi selain menunjukkan bahwa unsur pokok dalam peperangan adalah strategi. Kata perang tidak hanya dimaknai dengan menggunakan senjata, fisik dan kekerasan semata, akan tetapi pada segala aspek kehidupan selalu ada perang atau pertarungan, antara kebaikan dan kejahatan, serta antara hak dan batil. Jika tidak ingin dikalahkan, maka harus mengalahkan lawan. Salah satu caranya dengan membuat strategi. ${ }^{24}$ Contoh lain:

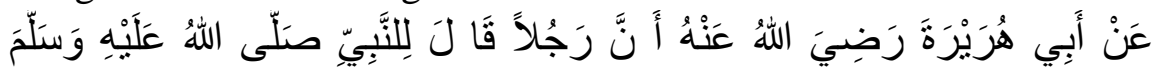

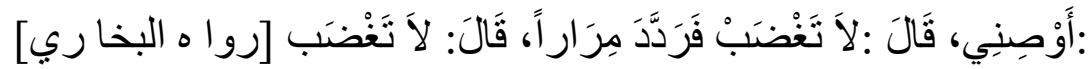

Artinya: Dari Abu Hurairah radhiyallahuanhu sesungguhnya seseorang telah bertanya kepada Rasulullah shalallahu 'alaihi wasallam: (Ya Rasulullah) nasihatilah saya. Beliau bersabda: Jangan kamu marah. Beliau menanyakan hal itu berkali-kali. Maka beliau bersabda: Jangan engkau marah. (HR. Bukhari)

Berdasarkan hadis di atas, Nabi saw., menyampaikan pesan yang singkat namun berisi makna yang padat. Marah bukanlah solusi yang tepat dalam menyelesaikan masalah, selain itu, marah juga membuat manusia lepas control dan mengikuti hawa nafsu. Marah dalam perspektif Kesehatan juga sangat merugikan tubuh dan jiwa serta masih banyak lagi aspek yang dikandung oleh pesan Nabi tersebut.

${ }^{24}$ Syuhudi Ismail, Hadis Nabi Yang Tekstual Dan Kontekstual, (Jakarta : Bulan Bintang : 1988), 11 


\section{Tamsil}

Tamsil merupakan suatu ungkapan bahasa yang berbentuk "perumpamaan" atau mempersamakan sesuatu dengan sesuatu yang lain. Dalam Bahasa Indonesia biasa disebut dengan "pribahasa"; hanya saja jika bahasa pribahasa selalunya singkat dan populer, dan membandingkan satu hal dengan satu hal yang lain. Sedangkan bahasa tamsil dalam hadis, seperti halnya bahasa tamsil (al-matsal) al-Qur"an, tidak hanya mempersamakan sesuatu dengan sesuatu yang lain secara ekual, tetapi persamaannya selalu lebih banyak..$^{25}$ Contoh hadis yang mengandung bahasa tamsil:

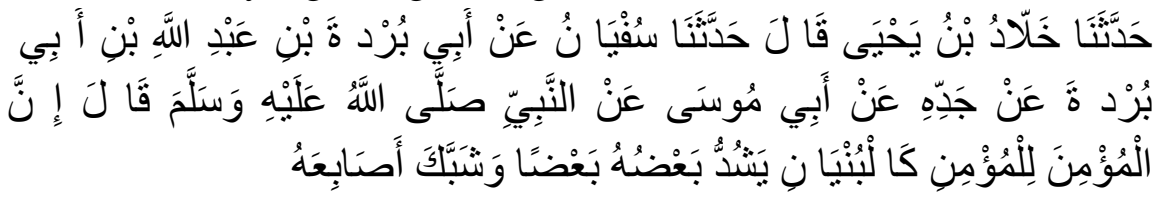

Artinya: "sesungguhnya orang yang beriman terhadap orang yang beriman yang lain ibarat bangunan, bagian yang satu memperkokoh bagian yang lain dan jari-jemarinya berjalinan" 26

$$
\text { المؤمن للمؤمن كالبنيان يشد بعضه بعضا (رو اه بخاري) }
$$

Artinya: Orang yang beriman terhadap orang yang beriman lainnya ibarat bangunan: bagian yang satu memperkokoh terhadap bagian lainnya. (HR. Bukhari).

Hadis Nabi tersebut berisi tamsil bagi orang-orang yang beriman yang diumpamakan seperti bangunan. Tamsil tersebut sangatlah logis dan berlaku tanpa terikat oleh waktu dan tempat, oleh karena setiap bangunan pastilah antara satu bagian dengan bagian yang lainnya berfungsi saling memperkokoh. Orang yang beriman begitu pula seharusnya. Dalam artian orang yang satu

${ }^{25}$ Zakiar, Bahasa Tamsil Hadis dalam Kitab Riyadush shalihin: Kajian Bab Menjaga Sunnah-sunnah Nabi saw.,Jurnal Islamika : Jurnal Ilmu-ilmu Keislaman, Vol. 18, No. 02, Desember 2018

${ }^{26}$ Al Bukhri, Shahih Bukhari, 289. Maktabah Syamilah. 
136 Rausyan Fikr, Vol. 17 No. 1 Januari 2021: 119 - 143.

memperkuat yang lainnya dan tidak berusaha untuk saling menjatuhkan. ${ }^{27}$

Dari aspek kebahasaan, matan tersebut mengandung ungkapan gaya bahasa tasybih tamsil jika ditinjau dari wajah syibhnya. Tasybih tamsil yakni bila wajah syibh-nya berupa suatu gambaran yang dirangkai dari keadaan beberapa hal dari Rasulullah saw., menyerupakan dua orang mukmin dengan sebuah bangunan yang bagian-bagiannya saling menguatkan. Musyabbah dalam hadis Nabi di atas berupa hubungan antara seorang mukmin dengan mukmin lainnya; musyabbah bih-nya ialah bangunan yang bagianbagiannya saling memperkokoh atau memperkuat; sedang wajah syibh-nya yaitu gambaran bagian-bagian bangunan yang memperkuat sebuah bangunan sehingga kokoh.

\section{Ramzi}

Ramzi atau dikenal dengan ungkapan atau model bahasa Nabi menyampaikan berita dalam bentuk simbol. Dalam ungkapan berbentuk simbolik, terkadang mengundang perbedaan pendapat. Bagi orang yang berpegang pada pernyataan secara tekstual dari sebuah hadis, maka ungkapan yang bersangkutan dinyatakan sebagai bukan simbolik. Adapun contoh bentuk matan mengandung ramzi sebagai berikut:

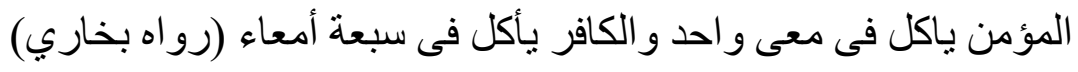

Artinya: "Orang yang beriman itu makan dengan satu usus (perut) sedang orang kafir makan dengan tujuh usus" (HR. Bukhari)

Bagi penganut tekstual maka hadis di atas, dapat dimaknai bahwa ususnya orang yang beriman berbeda dengan ususnya orang kafir. Padahal dalam kenyataan yang sesungguhnya, perbedaan anatomi tubuh pada manusia tidak dibedakan oleh perbedaan imannya. Dengan demikian, pernyataan hadis itu merupakan ungkapan simbolik. Itu berarti harus dipahami secara kontekstual.

${ }^{27}$ Syuhudi Ismail, Hadis Nabi Yang Tekstual ..., 14 
Perbedaan makna usus dalam matan hadis diatas menunjukkan sebagai sebuah perbedaan sikap atau pandangan dalam menghadapi nikmat Allah Swt termasuk ketika makan. Orang yang beriman berpendapat bahwa makanan bukan sebagai tujuan hidupnya. Untuk itu, orang yang beriman mestinya tidak banyak menutut dalam kelezatan makanan. Yang banyak menuntut kelezatan makanan umumnya orang kafir. Di samping itu, dapat dipahami juga bahwa orang yang beriman selalu bersyukur dalam menerima nikmat Allah, termasuk tatkala makan, sedagkan orang kafir mengingkari nikmat Allah yang dikaruniakan kepadanya. ${ }^{28}$

\section{Bahasa Percakapan}

Nabi Muhammad saw., merupakan manusia yang juga berinteraksi dengan manusia lainnya. Dalam kapasitasnya sebagai Nabi maka banyak yang menimba ilmu kepadanya. Dengan demikian, percakapan tidak dapat dihindari. Hal inilah yang dimaksudkan dengan hadis bergaya Bahasa dialog atau percakapan. Di bawah ini salah satu contoh hadis dengan model percakapan, seperti berikut ini:

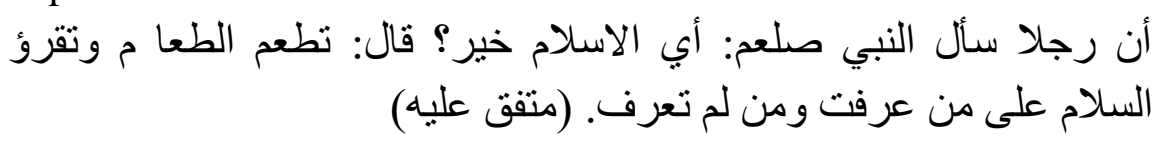

Artinya: Ada seorang lelaki bertanya kepada Nabi: "amalan Islam yang manakah yang lebih baik? "Nabi lalu bersabda: "kamu memberi makan orang yang menghajatkannya, dan kamu menyebarkan salam kepada orang yang kamu kenal (tahu) dan orang yang tidak kamu kenal (tidak tahu)" (Muttafaq Alaih).

Makna memberi makan orang yang menghajatkannya dan menyebarkan salam memang merupakan salah satu ajaran Islam yang sangat universal. Namun dalam hal sebagai melaksanakan "amal yang lebih baik", maka hadis Nabi saw tersebut dapat berkedudukan sebagai temporal atau sementara, sebab ada beberapa

${ }^{28}$ Syuhudi Ismail, Hadits Nabi Yang Tekstual..., 21 
matan hadis lainnya yang memberi petunjuk tentang amal yang lebih baik, namun jawaban Nabi tentang amal yang lebih baik tersebut berbeda-beda. ${ }^{29}$ Dalam memberikan jawaban, Nabi berbeda-beda menjawabnya. Hal ini menunjukkan bahwa kondisi penanya atau "lawan bicara" yang berbeda pula. Terbukti dengan adanya jawaban tentang "amalan yang lebih" pada kondisi penanya dalam hadis lainnya.

\section{Ungkapan Analogi}

Analogi dapat diartikan sebagai kesamaan, keserupaan, atau perbandingan. Dengan demikian, analogi disebut juga perbandingan secara kias dengan bentuk yang sudah ada. Ungkapan analogi tersebut memperlihatkan adanya hubungan ungkapan yang sangat logis dan dapat diterima oleh akal. Salah satu bentuk "nalar logis" yang biasa dipraktikkan Nabi dapat dijumpai dalam hadis berikut:

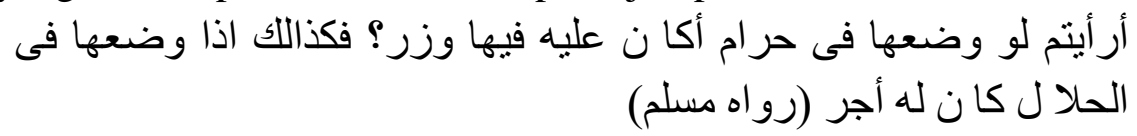

Artinya: "Bagaimanakah pendapatmu sekiranya hasrat seksual seseorang disalurkannya di jalan yang haram, apakah diamenanggung dosa? Maka demikianlah, bila hal tersebut disalurkan ke jalan yang halal (yang diridhai), dia mendapat pahala." (HR. Muslim) ${ }^{30}$

Matan hadis di atas, merupakan jawaban yang dikemukakan atas pertanyaan tentang menyalurkan hasrat seksual (kepada wanita yang halal) adalah sedekah. Pernyataan Nabi dalam hadis di atas diasumsikan sebagai bentuk ungkapan analogi, yang menyebutkan bahwa penyaluran hasrat seksual secara haram adalah perbuatan dosa, maka penyaluran hasrat seksual secara halal merupakan perbuatan yang bernilai pahala. Dengan demikian dapat dinyatakan bahwa secara tekstual hadis tersebut telah memberi petunjuk

\footnotetext{
${ }^{29}$ Syuhudi Ismail, Hadits Nabi Yang Tekstual..., 25

${ }^{30}$ Shahih Muslim, Juz II hal. 697-698
} 
tentang ajaran Islam yang bersifat universal sebab ketentuan itu berlaku untuk semua waktu dan tempat. ${ }^{31}$ Contoh pada hadis lain:

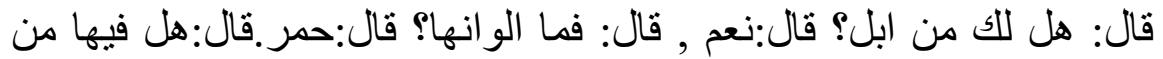

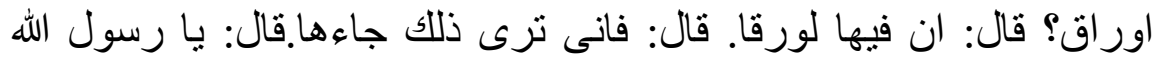

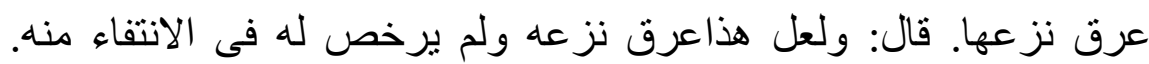

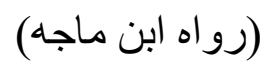

Artinya: Nabi bertanya: "apakah kamu mempunyai unta?", pria tersebut menjawab: "ya". Nabi bertanya lagi: "apa warna untamu itu?", priai tersebut menjawab: "merah", Nabi bertanya lagi: "apakah (mungkin untamu itu) dari (keturunan unta) yang berkulit abu-abu?", pria tersebut menjawab: "sesungguhnya (mungkin saja) unta itu berasal dari (unta yang) berkulit abu-abu". Nabi bersabda: "sesungguhnya saya menduga (bahwa unta merah milikmu itu) berasal dari (unta yang berkulit abu-abu tersebut)", pria itu menjawab: "Ya Rasul, keturunan (unta merahku itu) berasal dari unta abu-abu tersebut". Nabi lalu mengatakan: "(masalah anakmu yang berkulit hitam tersebut) semoga berasal juga dari keturunan (nenek moyang)-nya; dan (nenek moyang anakmu yang kulit hitam itu) tidaklah menurunkan keturunan yang menghilangkan (tanda-tanda keturunan) darinya. ${ }^{32}$

Hadis di atas berbicara tentang adanya pertanyaan seorang laki-laki dari bani Fazarah mengadu kepada Nabi. Dengan menceritakan kasusnya, bahwa istrinya telah melahirkan seorang anak laki-laki, kulitnya hitam. Laki-laki tersebut menyangkalnya (karena kulitnya berbeda sekali dengan kulit saya). Dalam hadis di atas, Nabi saw., menjawab tidak dalam Bahasa terbuka yang

${ }^{31}$ Syuhudi Ismail, Hadits Nabi Yang Tekstual...,38

32 Al Bukhari, Shahih Bukhari, al-Fath, 15/293, no. 4119 
140 Rausyan Fikr, Vol. 17 No. 1 Januari 2021: 119 - 143.

mungkin saja dapat membuat malu atau merendahkan penanya, tetapi Nabi saw., menjawab dengan memberika, analogi atau qiyas atau mempersamakan kasusnya dengan sosok lain. Inilah sebenarnya salah satu keistimewaan Nabi, yakni tidak langsung memberikan jawaban secara instan, melainkan memberikan kesempatan penanya untuk berfikir sekaligus memotivasi potensi akal.

\section{KESIMPULAN}

Fungsi umum hadis sebagai bayan terhadap Alquran tampak dari keberadaan matan yang bersifat operasional, yaitu menjelaskan ataupun merinci pesan yang akan diimplementasikan oleh umat Islam dalam kehidupan. Hadis tak hanya memuat pesan-pesan doktrin yang secara tersurat dalam matannya, yang terkadang dipahami secara tekstual sehingga membatasi teks-teks tersebut dalam rentang waktu tertentu. Lebih dari itu, hadis juga memiliki tujuan-tujuan moral yang merupakan dimensi terpenting dari teksteks hadis. Untuk itu, hadis perlu diberi pemahaman agar tetap responsif terhadap zaman.

Dalam sejarahnya, pemahaman terhadap matan sudah memiliki embrio pada masa Nabi saw., namun kondisi tersebut belum mendapat kendala disebabkan sumber berita masih bisa meluruskan setiap makna yang terkandung pada matan. Seiring perkembangannya, banyak ilmuan hadis yang mewarnai studi pemahaman hadis sehingga melahirkan banyak metode, Teknik, pendekatan atau pun corak. Semuanya sangat layak mendapat apresiasi, sebab tidak mudah memahami matan hadis tanpa menggunakan alat ukur untuk mengelaborasi maknanya.

Salah satu alat yang dapat dipergunakan untuk memahami matan hadis adalah mengetahui bentuk Bahasa atau model ungkapan Nabi saat menyampaikan berita atau jawaban. Corak atau model atau pun bentuk tersebut adalah ungkapan Bahasa yang singkat padat namun bermakna (jawamil kalim), penyampaian 
berita melalui perumpamaan (tamsil), mempersamakan (analogi), penyampaian simbolik (ramzi), dan dialog (percakapan).

Kelima model atau bentuk penyampaian pesan dalam matan hadis di atas sudah pasti memiliki tujuan, yaitu

1. Memperlihatkan keluhuran Bahasa yang keluar dari seorang utusan Allah swt.,

2. Menjaga marwah seorang Rasul dengan ketegasannya

3. Menjaga perasaan lawan bicara atau penanya agar tetap tidak merasa dipermalukan dalam setiap pertanyaan.

4. Menunjukkan keluasan wawasan dalam mengemas strategi dakwah Nabi saw.,

5. Memotivasi potensi akal umat Islam untuk terus menggali makna yang dikandung atas pesan-pesan dalam matan hadis.

\section{DAFTAR PUSTAKA}

Al-Adlabi, Salahuddin ibn ahmad, Manhaj Naqd al-matn Ind Ulama' al Hadits al-Nabawi, alih bahasa H. M Qodirun Nur ahmad Musyafiq, Metodologi Kritik Matan Hadits. Cet. I; Jakarta: Gaya Media Pratama, 2004.

Ahmad, Arifuddin, Paradigma Baru Memahami Hadits Nabi, Refleksi Pemikiran Pembaruan Prof. Dr. Muhammad Syuhudi Ismail. Cet. I; Jakarta: Renaisan, 2005.

Ahmad, H. Muhammad, M. Mudzakir, Ulumul hadits. Cet. III; Bandung: CV. Pustaka Setia, 2004.

Amin, Kamaruddin, Menguji Kembali Keakuratan Metode Kritik Hadis, Cet. I, Jakarta: Penerbit Hikmah, 2009

Azami, MM, Studies in Hadith Methodology and Literature, (Indiana, Amerikan TrustPublication, 1992)

Ahmad al-Qastalani, Irsyad al-Sari Li Syarh Sahih\{ al-Bukhari, jilid II (Beirut: Dar al-Fikr, 1990), 713.

Al-Bukhari al-Ja'fi, Abu Abdillah Muhammad Ibn Ibrahim bin alMughirah bin Bardzabah, Shahih Bukhari, Juz V. Beirut: Dar al-Kutub al-Ilmiyah, 1996. 
142 Rausyan Fikr, Vol. 17 No. 1 Januari 2021: 119 - 143.

Al-Asqalani, Ahmad bin Ali bin Hajar, Fathul Bari Juz 10, t.tp.: AlMaktabah al-Salafiyah, t.th.

Departemen agama RI., Al-Qur'an dan Terjemahnya. Jakarta: PT. Syamil Cipta Media, 2005.

Al-Ghazali, Syaikh Muhammad, As-Sunnah An-Nabawiyyah: Baina ahl Fiqh wa Ahl al-Hadits, diterjemahkan oleh Muhammad Al-Baqir dengan judul Studi Kritis atas hadits Nabi Saw. Cet. VI; Bandung: Mizan, 1989.

Arifin, Muhammad Patri, "Obat Penawar dan Penyakit di Sayap Lalat (Integrasi-Interkonektif Hadis dengan Ilmu Pengetahuan)", al-Munir: Jurnal Studi Ilmu al-Qur'an dan Tafsir, Vol. 2, No. 2 Juli 2020.

M. Syuhudi Ismail, Hadits Nabi menurut Pembela, Pengingkar dan Pemalsunya. Cet. I; Jakarta: Gema Insani Press, 1995.

-------, Hadits Nabi yang Tekstual dan Kontekstual, (Tela'ah Ma'ni al-Hadits tentang Ajaran Islam yang Universal, Temporal dan Lokal). Cet. I; Jakarta: PT. Bulan Bintang, 1994.

-------, Metodologi Penelitian Hadits Nabi. Cet. I; Jakarta: PT. Bulan Bintang, 1992. Al-Nawawi, Al-imami Muhyiddin, Syarah Shahih Muslim, Juz I. Beirut: dar alMa'rifah, 1996.

Iqbal, Muhammad, Recontruction of Religius Though in Islam, (New Delhi: Kitab Bhavan, 1981 M.

Nata, Abuddin, Metodologi Studi Islam, (Cet. II; Jakarta: PT. Rajagrafindo Persada, 2007)

Al-Qardhawi, Yusuf, Kaifa Nata'amalu ma'a al-Sunnah alNabawiyyah, diterjemahkan oleh Saifullah Kamalie Metode Memahami As-Sunnah dengan Benar. Jakarta: Media Da'wah, t.th.

Al-Qusyairi al-naisaury, Abu Husain Muslim bin Hujjaj Shahih Muslim, Juz III. Beirut: Dar al-kutub al-Ilmiyah, 1996. 
Al-Madhal li al-Dirasah al-Sunnah al-Nabawiyyah, alih bahasa, Agus Suyadi Raharusun, Pengantar Studi Hadits. Cet. II: Bandung: Pustaka Setia, 2007.

Poerwadarminta, W.J.S., Kamus Umum Bahasa Indonesia (Jakarta: Balai Pustaka, 1985)

Saman, Bustamin, M. Isa H.A., Metodologi Kritik Hadits, Cet. I; Jakarta: PT. Raja Grafindo Persada, 2004.

Zailani, Metode Intertekstual Memahami Hadis Nabi, (AL-Fikra: Jurnal Ilmiah Keislaman, Vol. 15, No. 2, Juli Desember 2016)

Zakiar, Bahasa Tamsil Hadis dalam Kitab Riyadush shalihin:

Kajian Bab Menjaga Sunnah-sunnah Nabi saw., Jurnal Islamika: Jurnal Ilmu-ilmu Keislaman, Vol. 18, No. 02, Desember 2018 